\title{
ARSENAL OF DEMOCRACY IN THE FACE OF CHANGE: PRECISION GUIDED MUNITIONS (PGMS) THEIR EVOLUTION AND SOME ECONOMIC CONSIDERATIONS, WORKING PAPER NO. 4
}

\author{
C. V. Chester \\ Date Published: August 1990
}

Prepared for the

FEDERAL EMERGENCY MANAGEMENT AGENCY

Washington, D.C. 20472

Under Interagency Agreement No. FEMA EMW-84-E-1737

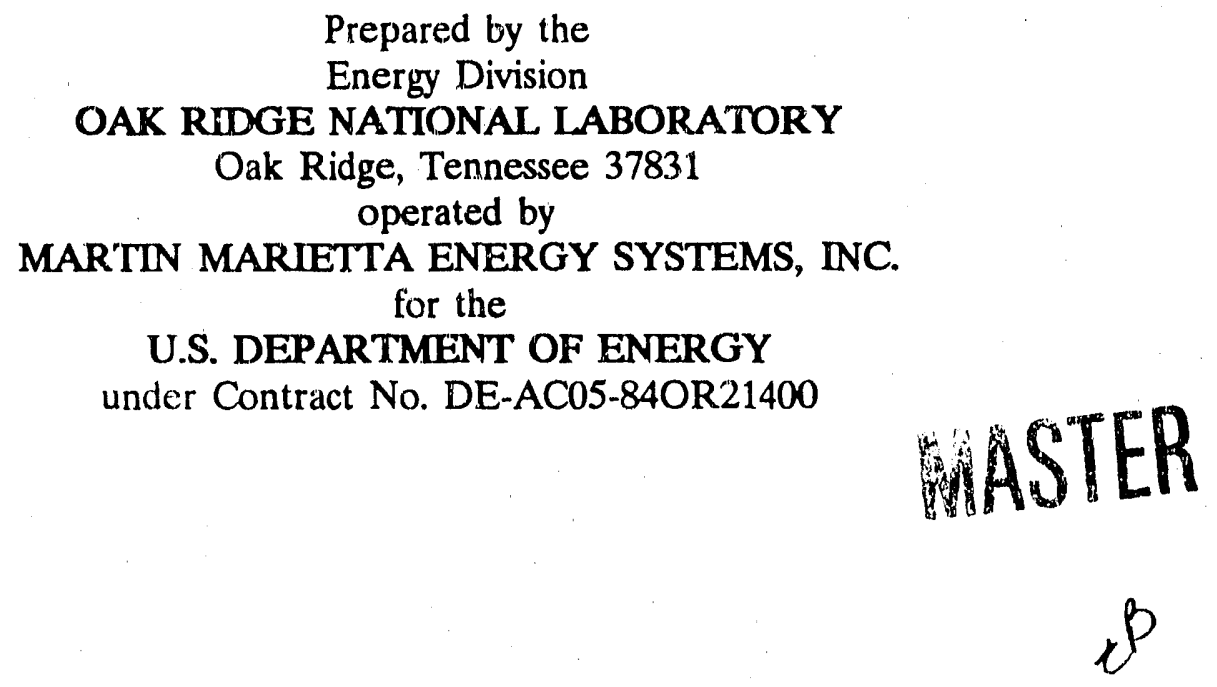




\section{CONTENTS}

ABSTRACT $\ldots \ldots \ldots \ldots \ldots \ldots \ldots \ldots \ldots \ldots \ldots \ldots \ldots \ldots \ldots \ldots$

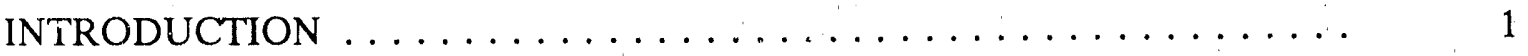

THE ROAD TO PGM's: THE QUEST FOR RANGE AND ACCURACY 2

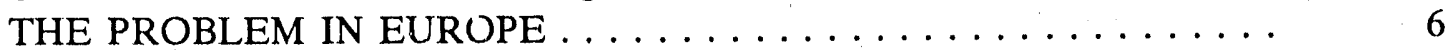

THE AIR LAND BATTLE OR FOLLOW-ON FORCE ATTACK (FOFA) 8

COMBAT EXPERIENCE WITH PGM's . . . . . . . . . . . 9

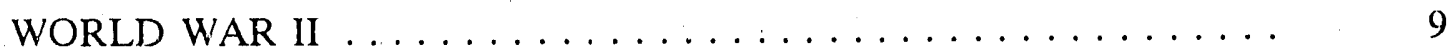

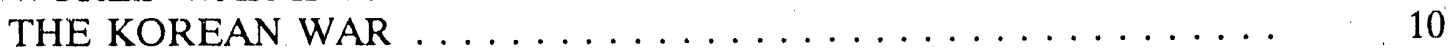

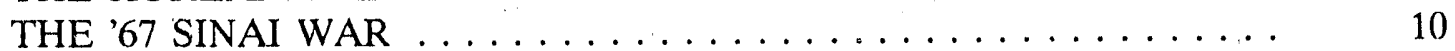

VIETNAM ........................ 11

THE WAR OF ATTRITION AND THE YOM KIPPUR WAR - 1973 . . 12

THE FALKLANDS WAR 1982 (AWST July 19, 1982) . . . . . . . . . . . . . 14

LEBANON 1982 THE BEKAA VALLEY . . . . . . . . . . . . . . . . 14

AFGHANISTAN $1979-1988 \ldots \ldots \ldots \ldots \ldots \ldots \ldots \ldots$

COST AND OTHER PROPERTIES OF SOME IMPORTANT U.S. PGM'S . 16

ESCALATION OF AIRCRAFT COSTS SINCE WORLD WAR II . . . 19

FUTURE DIRECTIONS OF TECHNOLOGY . . . . . . . . . . . 24

CONCLUSIONS $\ldots \ldots \ldots \ldots \ldots \ldots \ldots \ldots \ldots \ldots \ldots \ldots \ldots \ldots \ldots$

BIBLIOGRAPHY .......................... 29

ORNL Project Working Papers for

Arsenal of Democracy in the Face of Change . . . . . . . . . . . 31

LIST OF ACRONYMS $\ldots \ldots \ldots \ldots \ldots \ldots \ldots \ldots \ldots \ldots \ldots \ldots$ 


\section{LIST OF TABLES}

Table 1. NATO'S force comparison . ............... 7

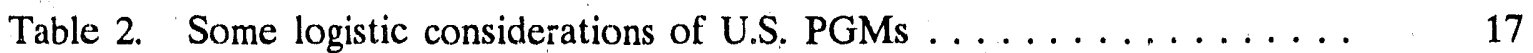

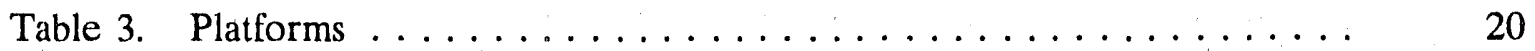

Table 4. Escalation of aircraft costs since World War II . . . . . . . . . 21

Tabie 5. Cost of some conventional munitions . . . . . . . . . . . . 23 


\title{
ABSTRACT \\ ARSENAL OF DEMOCRACY IN THE FACE OF CHANGE: PRECISION GUIDED MUNITIONS (PGMs) THEIR EVOLUTION AND SOME ECONOMIC CONSIDERATIONS, WORKING PAPER NO. 4
}

\author{
C. V. Chester
}

\begin{abstract}
A brief study was made of some of the forces driving the move to Precision Guided Munitions (PGMs), including the quest for military effectiveness, combat experience, and logistic compression. PGMs cost from a few hundred to a few thousand dollars per $\mathrm{Kg}$ but are tens to hundreds of times more effective than conventional munitions. A year's peacetime plateau production of each U.S. PGM can be carried by a few C-5 aircraft. Surge quantities of PGMs are within U.S. airlift capabilities, taking some of the risk out of off-shore procurement. The improving capability of antiaircraft PGMs and the escalating cost of combat aircraft (50 to 100-fold in constant dollars since WW II may bring into question the economic viability of manned attack aircraft. The same may be true to a slightly lesser degree for heavy armored vehicles.
\end{abstract}




\section{INTRODUCTION}

One thesis of this discussion is that Precision Guided Munitions (PGM's) are a natural extension of the two-century-old quest for the extension of range and accuracy of projectile weapons. We believe history supports the contention that this quest will continue, with successive improvements and countermeasure to PGM's.

Another observation about the high tech revolution in armament is the high cost or concentration of wealth in both PGM's and manned launch platforms, especially attack aircraft. For their high cost, PGM's give their possessor new capabilities: one-shot kills and more standoff distance. However, the improvement afforded the platforms against infantry pales by comparison to the improvement in capability the infantry has obtained against the platforms. Arming the infantry with large numbers of modern PGM's, and their prospective improveci models, bring into question the battlefield survivability of the platform. The extremely high costs of manned attack aircraft give it an unfavorable cost exchange ratio at attrition rates that were acceptable in the past.

The main battle tank and attack bomber evolved to compensate for limitations of infantry due to its vulnerability and limited firepower. It may be time to rethink the mix of platforms and infantry in an environment whe e both sides are deterred from using their nuclear and chemical weapons. The conclusions should affect decisions concerning the allocations of scarce resources for investment in surge and mobilization capability. 
Arsenal of Democracy in the Face of Change: Precision

Guided Munitions (PGMs) Their Evolution and Some Economic

Considerations; Working Paper No. 4.

\section{THE ROAD TO PGM's: THE QUEST FOR RANGE AND ACCURACY}

The basic objective of warfare is to take enemy territory and destroy the enemy forces. In most circumstances, the final arbiter of war has been the infantry -- armed soldiers on foot (Garden 1989). For most of history, the final battles have been fought with muscle-powered weapons: swords, spears, archery, and up to this century, the bayonet. The early gunpowder weapons were slow firing and inaccurate enough so as not to prevent military units from marching onto the battlefield, and rushing enemy positions in massed charges. The extension of range and increase in volume of fire afforded by early artillery was not enough to compensate for its scarcity and lack of mobility, and thus did not usually discourage standing attacks.

The development of the cylindro-conoidal rifle projectile in the 1850 's increased the rate of fire to several shots per minute per weapon and the effective range to a few hundred yards. This permitted members of a defending force, especially if they were behind cover or in trenches to get off up to 10 aimed shots at attacking infantry while the attackers were marching or running across the field of battle. Horrendous losses to attacking units resulted and were largely responsible for the tremendous carnage in the U.S. Civil War. Further increases in fire power, first through the deployment of breach loading rifles and then, the machine gun exacerbated the situation. The effective range and accuracy in the individual infantryman's weapon can be considered to have peaked just before World War I, with the deployment of the Springfield Model 1903 and the Mauser Model 98 rifles. Subsequent developments in individual combat weapons have gone in the direction of increased firepower: full- and semi-automatic operation, increased 
Arsenal of Democracy in the Face of Change: Precision

Guided Munitions (PGMs) Their Evolution and Some Economic

Considerations, Working Paper No. 4.

magazine capacity, and grenade-launching capability. The deployment of barbed wire made frontal assaults on prepared positions virtually impossible unless preceded by an artillery barrage or sappers to cut the wire.

Rapid-firing, breach-loading artillery developed as an extension in range and firepower to support friendly infantry made the battlefield environment even more lethal to the infantry of both sides. Artillery, in addition to providing fire support, was also used to attack enemy logistic activities and fortifications.

Early in World War I it was recognized that the losses entailed by upright charges of enemy fortifications were prohibitively expensive. This led to the "fire and maneuver" tactics developed by Gen. Eric Ludendorf in 1917. (Dupuy 1984). These tactics are still standard infantry combat tactics and used by most armies in the world today (U.S. Army 1982, 1984).

The technological countermeasure to the hail of lead and steel on the World War I battlefield was the development of the tank. The original concept was to move a machine gun and later a cannon up to enfilade the enemy trenches while protecting the crew. The early versions of the tank were lightly armored and vulnerable to the artillery of that time. There followed decades of improvement in tank armor, mobility, speed, and armament that made tanks themselves the principal anti-tank weapon. The race between improvements in armor and improvements in tank guns and tank killing munitions goes on to this day.

In open terrain, or areas with a good road network, tanks can be massed to function like cavalry. Fast-moving columns can overwhelm weak spots in the defensive line and penetrate to the rear and disrupt communications and logistics. 
Arsenal of Democracy in the Face of Change: Precision

Guided Munitions (PGMs) Their Evolution and Some Economic

Considerations, Working Paper No. 4.

Tanks represent a fairly mature line of research and development. Incremental improvements in gun caliber, projectile design and velocity, armor, engine power, night vision laser sights, and flame suppression provide transient advantages to one side or the other, to be overtaken by the next developmental cycle. However, their presence in large numbers $(50,000)$ in the Warsaw Pact Forces, has been responsible for intense development of anti-armor munitions of all types, including PGM's, by the NATO countries. Large numbers have been procured and many of them have been shown to be effective.

Early field artillery was developed to provide a significant increase in range and volume of fire over the frontline weapons used by the infantry. Modern artillery can be accurate enough to kill a tank at extreme range when equipped with a terminally-guided projectile, such as Copperhead and assisted by a forward observer illuminating the target with a laser designator. Aircraft can be considered an extension of artillery to ranges of hundreds of kilometers. Modern attack aircraft 'an carry impressive weights of munitions; an attack aircraft carrying 5 tons of ordnance has the same throw weight as a salvo by 100155 -millimeter guns. Aircraft provide a much softer lide than artillery pieces and munitions for air delivery can be more sophisticated, including "launch and leave" precision guidance. Tanks unaccompanied by anti-aircraft weapons systems are virtually defenseless against air attack. Operations with armored vehicles are almost impossible in open terrain if the enemy has complete air superiority.

Priorities in an air campaign include: (1) destruction of the enemy aircraft and enemy bases; (2) destruction or suppression of anti-aircraft defensive weapons used by the enemy, and (3) close 
Arsenal of Democracy in the Face of Change: Precision

Guided Munitions (PGMs) Their Evolution and Some Economic

Considerations, Working Paper No. 4.

air support of one's own forces and disruption of enemy logistics. A side with air superiority has the initiative on when to attack and where to attack. Furthermore, this side can conduct armored operations in daylight in the open. In a sense, combat aircraft are at the top of a predation chain; nothing hunts aircraft except other aircraft. Massed surface-to-air missiles (SAMs) can ambush aircraft and interdict airspace, but they are primarily defensive.

As in the cace of tanks, the power, expense, and capability of aircraft have stimulated a vigorous development program for high technology munitions that can counter air power. Among the earliest PGM's was a series of radar-guided surface-to-air missiles designed to attack highaltitude bombers. The first widely-deployed, air-to-air precision-guided munitions, the Sidewinder, was developed in the late 1950's. The speed and typical engagement distances of high performance jet aircraft are such that guns are usually less effective than air-to-air missiles.

A rather large array of ground-launched and air-launched anti-aircraft (and anti-tank) PGM's followed. These are effective over a wide variety of ranges, the longer range missiles generally costing more than the short range. They are variously radar-guided or infrared guided, and subject to a variety of countermeasures which can include strenuous evasive maneuvers, radarjamming, chaff and flares. High performance aircraft have no capability to occupy territony and very little capability against infantry which can dig in or be concealed in the terrain. $\mathrm{n}$ the other hand, effective shoulder launched PGM's are in large-scale production. Infantry attacking in large numbers in the open are vulnerable but not when dispersed and concealed.

Helicopters and tanks have some capability to occupy territory but both are vulnerable to PGM's carried by individual infantrymen. It is conceivable that technology has made weapon 
Arsenal of Democracy in the Face of Change: Precision

Guided Munitions (PGMs) Their Evolution and Some Economic

Considerations, Working 1 uper No. 4.

platforms such as the high performance aircraft, the tank and the helicopter, both unaffordably expensive and vulnerable to shoulder-launched, precision-guided munitions. It may be we have come full cycle with technology. We have so amplified the power of the infantryman, especially when fighting as a guerilla, that he will again be the final arbiter of the conflict. The results of the last two wars fought by the superpowers, Vietnam and Afghanistan, seem to indicate this trend.

\section{THE PROBLEM IN EUROPE}

NATO's problem in conducting offensive land operations in Europe can be inferred from Table 1. The Warsaw Pact forces enjoy numerical superiority over the NATO forces ranging from 5:1 in armored infantry fighting vehicles to $3: 1$ in divisions, main battle tanks and artillery pieces to $2: 1$ in combat aircraft to $3: 2$ in personnel and helicopters.

These numbers are offset by 3 factors. First, NATO has a defensive strategy. According to many military texts this confers a substantial advantage on the defender (see Dupuis 1982, 1984, Dupuy et al. 1979. Atkeson 1988, Holmes 1988). Secondly, Soviet technology may be inferior to that of the West. In the 1982 Battle of the Bekaa Valley in Lebanon (see below) Syrian-manned Soviet aircraft and anti-aircraft missiles were almost completely ineffective against Israeli-operated U.S. electronics and aircraft.

Thirdly, NATO has invested substantially in development and deployment of PGM's and other high-tech equipment. 


\begin{tabular}{lcrc}
\hline & NATO & WP & RATIO \\
& & 22,400 & $5: 1$ \\
Armored Infantry Fighting & 4,153 & & \\
Vehicles & & & \\
Armored Vehicle Launched & 454 & 2,550 & $5: 1$ \\
Bridges & & & \\
Divisions & & & $3: 1$ \\
Main Battle Tanks & $11-1 / 3$ & 51,500 & $3: 1$ \\
Artillery Pieces & 16,424 & 43,400 & $3: 1$ \\
& 14,458 & & \\
Air Defense Systems & & 24,400 & $5: 2$ \\
Other Armored Vehicles & 10,309 & 71,000 & $2: 1$ \\
Antitank Weapons & 35,351 & 44,200 & $2: 1$ \\
Combat Aircraft & 18,240 & 8,250 & $2: 1$ \\
Penionnel & 3,977 & 3,700 & $3: 2$ \\
Helicopters & $2,213,593$ & $3,090,000$ & $3: 2$ \\
& 2,419 & & \\
\hline
\end{tabular}

${ }^{a}$ Outside National Territory

From J. H. Milam and D. A. Ruiz Palmer, "Conventional Forces in Europe' What's in the Graphs?" Armed Forces Journal Jan. 89, pp. 47-52. 
Arsenal of Democracy in the Face of Change: Precision

Guided Munitions (PGMs) Their Evolution and Some Economic

Considerations, Working Paper No. 4.

\section{THE AIR-LAND BATTLE OR FOLLOW-ON FORCE ATTACK (FOFA)}

The Air/Land battle is the name of the doctrine adopted in 1982 to try to counter the Warsaw Pact superiority in conventional forces in an attack by them on Western Europe (Homes, 1988). The general idea of the plan is to stop the first echelon of the Soviet attack with NATO ground forces, and to simultaneously launch air attacks using large numbers of precision-guided munitions against the second and third echelons of the Soviet forces to prevent them from coming to the support of the first echelon. The information on the location and composition of the Warsaw Pact Forces would be obtained by high-flying aircraft in West European territory by observing, identifying, and locating radar emissions by a system called Precision Iocation Strike System (PLSS) carried by TR-1 very high-altitude aircraft and active adar in the Joint Surveillance and Target Attack Radar System (J-STARS). Targets identified would be attacked with long-range artillery barrages, remotely piloted vehicles (RPVs), possible robotic devices, mines, and the air-launched weapons that seek and destroy armor (SADARM). This approach is also called the follow-on force attack (FOFA). It is completely dependent on high tech munitions, some of which have not been procured (Gliksman 1989). 


\section{COMBAT EXPERIENCE WITH PGM's}

\section{WORLD WAR II}

With electronics limited to vacuum tube circuits the opportunities for development of PGM's were quite limited in World War II. There was some experimentation with a remotelycontrolled bomb steerahle in azimuth only.

One of the outstanding developments in World War II was the development by the U.S. of the VT (for "variable time") or proximity fuze. The fuze contained a small radar set which was activated after the projectile was launched, and then exploded the projectile when it got within a preset distance of a radar reflector. It converted near-misses into hits. The critical development which made the VT fuze possible was a vacuum tube which could withstand the acceleration of thousands of time's that of gravity when the projectile was launched. While not providing directional guidance to the projectile, the VT fuze did regulate trajectory length, producing a dramatic improvement in lethality.

Late in the war, as a desperation measure, the Japanese developed a highly cost-effective and successful, precision-guided weapon with their suicide-piloted Kamakazi aircraft. This consisted of a Zero or other aircraft fitted with a 500-lb. bomb and a young pilot taught just enough flying to take the aircraft off, hold it loosely in formation, and dive it onto a U.S. ship. The weapon was very effective, resulting in the sinking of 34 and damage of 288 U.S. ships in the Battle of Letye Gulf in the Phillipines and the invasion of Okinawa (Jablonski, 1972). One thousand two hundred 
Arsenal of Democracy in the Face of Change: Precision Guided Munitions (PGMs) Their Evolution and Some Economic Considerations, Working Paper No. 4.

twenty-eight Japanese aircraft were expended. Fear of the use of this technique using thousands of Japanese planes during a U.S. invasion of Japan has been given as one of the reasons for the decision to use the atomic bomb.

\section{THE KOREAN WAR}

The Korean War was fought with World War II weapons and tactics for the most part, coming as closely after as it did. It was marked by the large-scale use of jet aircraft as interceptors, and radar-controlled anti-aircraft guns. VT fuzes were used extensively by U.S. forces.

\section{THE '67 SINAI WAR}

This war was a nearly flawless example of blitzkreig warfare. It opened with a surprise attack by Israeli aircraft on Arab, particularly Egyptian, airbases destroying over one-half their inventory of aircraft, and putting the runways out of commission with concrete-piercing bombs. Simultaneously, Israeli armored columns thrust into the Sinai picking off Egyptian tanks with their up-gunned Sherman tanks. With the return of Israeli aircraft to the close air support mission, the Egyptian forces disintegrated and surrendered en mass. After taking the West Bank of the Jordan River and the Golan Heights, Israel agreed to the UN proposed cease fire. Israeli success in destroying Arab aircraft on the ground and markmanship with "dumb" weapons left a reduced role for the much more expensive PGM's, although some air-to-air missiles were used.

There is a postscript to the war after the cease-fire. The Israeli destroyer Eilat was destroyed by Soviet-built "Styx" radar-guided cruise missiles fired from Egyptian patrol boats. 
Arsenal of Democracy in the Face of Change: Precision

Guided Munitions (PGMs) Their Evolution and Some Economic

Considerations, Working Paper No. 4.

\section{VIETNAM}

The late stages of the Vietnam war saw the beginning of significant use of precision-guided missiles in combat. The North Vietnamese used Soviet-built SAM 2 "Guideline" missiles against U.S. bombers attacking targets in North Vietnam. The U.S. used precision-guided weapons, notably the TV-guided glide bomb "Walleye" against bridges and other high-value targets in North Vietnam. These PGM's, though expensive, turned out to be highly cost-effective. They were used against the Than Hoa and Paul Doumier bridges in North Vietnam that had previously withstood attacks by scores of aircraft, entailing the loss of respectively 8 and 10 aircraft in the process. In each case, they were taken out by the first attack using PGM's (Holmes, 1988, p. 290).

The U.S. also used Sidewinder heat-seeking, anti-aircraft missiles and Shrike anti-radiation missiles in the air war over North Vietnam. The North-Vietnamese quickly learned to shut down their radars when they detected the approach of Shrike-carrying aircraft. However, this tactic did take them out of the battle.

PGM's are of very limited use against infantry spread around in the jungle, and in caves and tunnels. They also were of little use against artillery dug into close fitting earthworks in the jungle. The Vietnam war is an example of a war where technological superiority, air superiority, and military superiority was not enough to win the war although the side with them never lost a major 
Arsenal of Democracy in the Face of Change: Precision

Guided Munitions (PGMs) Their Evolution and Some Economic

Considerations, Working Paper No. 4.

battle. Massive technological superiority and fire power were neutralized by dispersion, concealment, tenacity, and clarity of objective.

\section{THE WAR OF ATTRITION AND THE YOM KIPPUR WAR - 1973}

The 1973 Yom Kippur War can be considered a second round of the 6-Day War in 67. The War of Attrition lasted from 1967 to 1973. Egyptian forces conducted raids into the Sinai provoking Israeli air attacks against Egypt. To prevent the Israeli attacks, the Egyptians deployed Soviet-built SAM-2 and SAM-3 missiles in fixed sites and had SAM-6, SAM-7 and ZSU23/4 mobile anti-aircraft systems west of the Suez Canal. The Sam-2 and Sam-3 slant ranges permitted antiaircraft coverage of much territory east of the Suez Canal in the 73 war. (Holmes, 1988, p. 288).

The Egyptians coming across the canal in October were armed with Soviet-built Sagger-3 and RPG-7 anti-tank missiles. The Sagger 3 is a wire-guided anti-tank missile, less effective but similar in some respects to the TOW. The combination of SAMs and anti-tank missiles turned out to be highly effective, at least at the beginning. In the first 48 hours, the Israelis lost $14 \%$ of their frontline aircraft to Egyptian and Syrian anti-aircraft defenses. The second day of the war, the 190th Israeli Army Brigade attempted a counterattack against the Egyptian Second Army on the east bank of the Suez Canal. The Brigade went though Egyptian positions leaving many pockets of resistance in their rear. They apparently outran their logistics and follow-up forces losing 34 tanks to the Egyptians' RPG7 and Sagger 3's. They finally became cut off, and out of fuel and ammunition, were forced to surrender: the Egyptian Second Army without air cover and very much armor, managed to wear down and then capture an Israeli armored column. The SAMS 
Arsenal of Democracy in the Face of Change: Precision

Guided Munitions (PGMs) Their Evolution and Some Economic

Considerations, Working Paper No. 4.

across the canal and the local SAMS 7's and anti-aircraft guns were able to keep the Israeli aircraft from delivering effective support to the beleaguered column.

The Israelis soon developed countertactics to deal with the problems presented by the Egyptian PGM's. To suppress the Sagger missiles, they accompanied armored columns with armored personnel carriers, carrying soldiers with automatic weapons. Soldiers fired from the APCs on positions that could potentially conceal a Sagger operator. To deal with the radarcontrolled anti-aircraft cannon and guided missiles Israeli aircraft came in low, under 50-ft (15 meters), and departed low. The radar of the anti-aircraft weapons could not pick up the Israeli aircraft in the ground clutter. The threat from the long-range SAM 2's on the West bank of the canal was neutralized when an Israeli armored column, accompanied by infantry, crossed the canal and sliced through the lightly defended missile positions.

The unexpectedly high lossen of Israeli armor and aircraft left their infantry with inadequate protection against Egyptian and Syrian armor. This situation was alleviated by emergency shipments of TOW missiles from the United States.

Consumption of PGM's was reported to greatly exceed plans. 
Arsenal of Democracy in the Face of Change: Precision

Guided Munitions (PGMs) Their Evolution and Some Economic

Considerations, Working Paper No. 4.

THE FALKLANDS WAR 1982 (AWST' July 19, 1982)

The high tech portion of this war was fought between Argentinean Entendard aircraft, Exocet missiles, and American-built A-4 aircraft against British ships, Harrier VTOL aircraft, and short-range anti-aircraft weapons launched by both Harriers and ships. Electronic countermeasures were used profusely by both British ships and aircraft, including especially chaff and flares. The Argentine A-4s were operating at the outer limit of their combat radius which permitted them little time over the target and severely restricted their ability to engage in dogfights with the British Hawker Harrier.

Public accounts of the war have been dominated by the sinking of the Atlantic Conveyor cargo ship and the HMS Sheffield, a destroyer. One of the points demonstrated in the brief war was the fact that hits could be made on ships hy aircraft using iron bombs, many of which failed to explode due to being released too close to the ship to arm before impact.

Consumption of PGM's, especially Sidewinders carried by the Harriers, was reported to be much larger than originally planned. The British were resupplied from U.S, stocks. The weapons supplied were the latest version with head-on intercept capability and are credited with a major contribution to the British victory.

\section{LEBANON 1982. THE BEKAA VALLEY}

This battle was notable for the lopsided success of the Israelis in the air war against Syrian anti-aircraft defenses. The Syrians moved about 120 Soviet-built SAM $6 \& 8$ launchers into the 
Arsenal of Democracy in the Face of Change: Precision

Guided Munitions (PGMs) Their Evolution and Some Economic

Considerations, Working Paper No. 4.

Bekaa Valley. These were destroyed in a coordinated attack using offshore Israeli radar jammers and spoofers, surveillance of Syrian air movements and communications, anti-radiation missiles, RPV's and drones to expose Syrian radars, and coordinated attacks against Syrian aircraft shortly after they took off. The final scors was about 120 Syrian anti-aircraft missile units and 90 highperformance fighters destroyed to no Israeli aircraft lost (Holmes 1988, AWST August 9, 1982). The lesson from this experience is that even sophisticated anti-aircraft defenses can be neutralized by a combination of good tactics and a good choice of weapons and countermeasures.

\section{AFGHANISTAN 1979-1988}

The war in Afghanistan is notable for the substantial deployment of the American made Stinger anti-aircraft missile against Soviet high performance aircraft and helicopters. It is reported (Sliwinski, 1989) that Soviet aircraft losses in 1986, about the time the Stinger was introduced, went from 27 in September to 73 in October. It is speculated that this was due in large part to the introduction of the Stinger missile. The Stinger virtually precluded helicopter operations and forced high performance jet aircraft to altitudes where their bombing of ground targets became much less effective. It is believed by many observers that this state of affairs had considerable effect on the Soviet decision to withdraw from Afghanistan.

The lessons from experience with PGM's are: they convey tremendous advantage on the user, especially when first introduced. Tactical and technological countermeasures are soon developed by the adversary, but the PGM's remain cost-effective and give the infantry a real 
Arsenal of Democracy in the Face of Change: Precision Guided Munitions (PGMs) Their Evolution and Some Economic Considerations, Working Paper No. 4.

capability against armor and low flying aircraft. Expenditure rates in combat are usually much higher than planned.

\section{COST AND OTHER PROPERTIES OF SOME IMPORTANT U.S. PGM's}

Table 2 is a list from unclassified sources (Nicholas \& Rossi, 1988, Janes 1989) of the more important U.S.-made PGM's along with their approximate weight, range, fiscal years acquired, number acquired (estimated through 1989), estimated plateau of the acquisition rate, a most recent cost per unit and the approximate cost per kilogram. This last is included to give some feeling for the density of wealth concentrated in these munitions. Also included is the weight of one year of each missile's peacetime plateau production in units of 100 tons. This is of the order of the material that could be loaded on a C-5A and flown to some theater of operations. For most missiles this corresponds to a few plane loads, 2 or 3 in many cases." Surge production would require three times this amount.

*To put this in perspective, a C-5 flying $20 \mathrm{hr}$ per day at $500 \mathrm{mph}$ will produce 1 million tonmiles per day. Pilesent U.S. airlift capability is 46 million ton miles per day with plans to go to 66 by the year 2000 (AWST $1 / 30 / 89$, p. 24). 


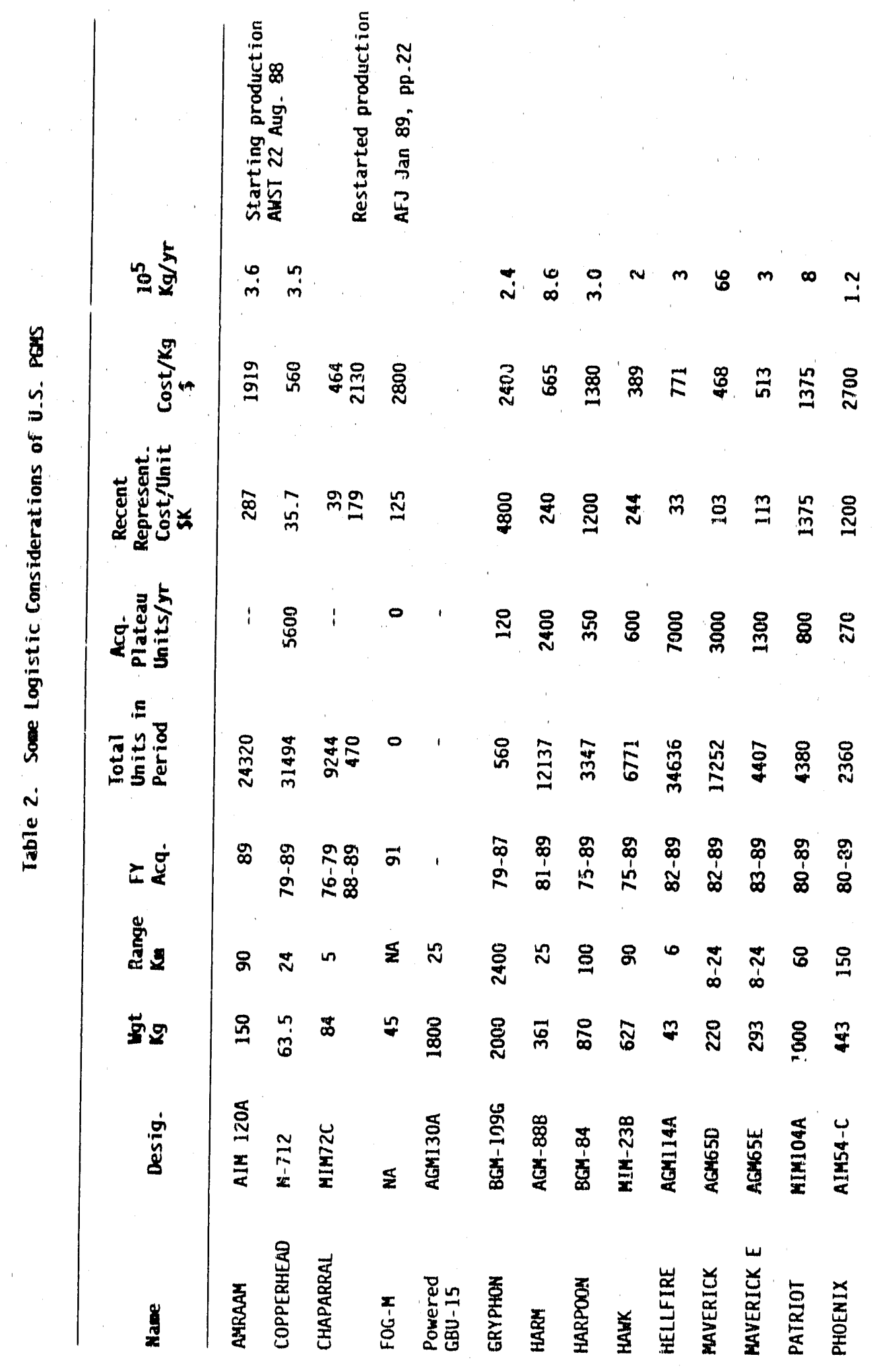




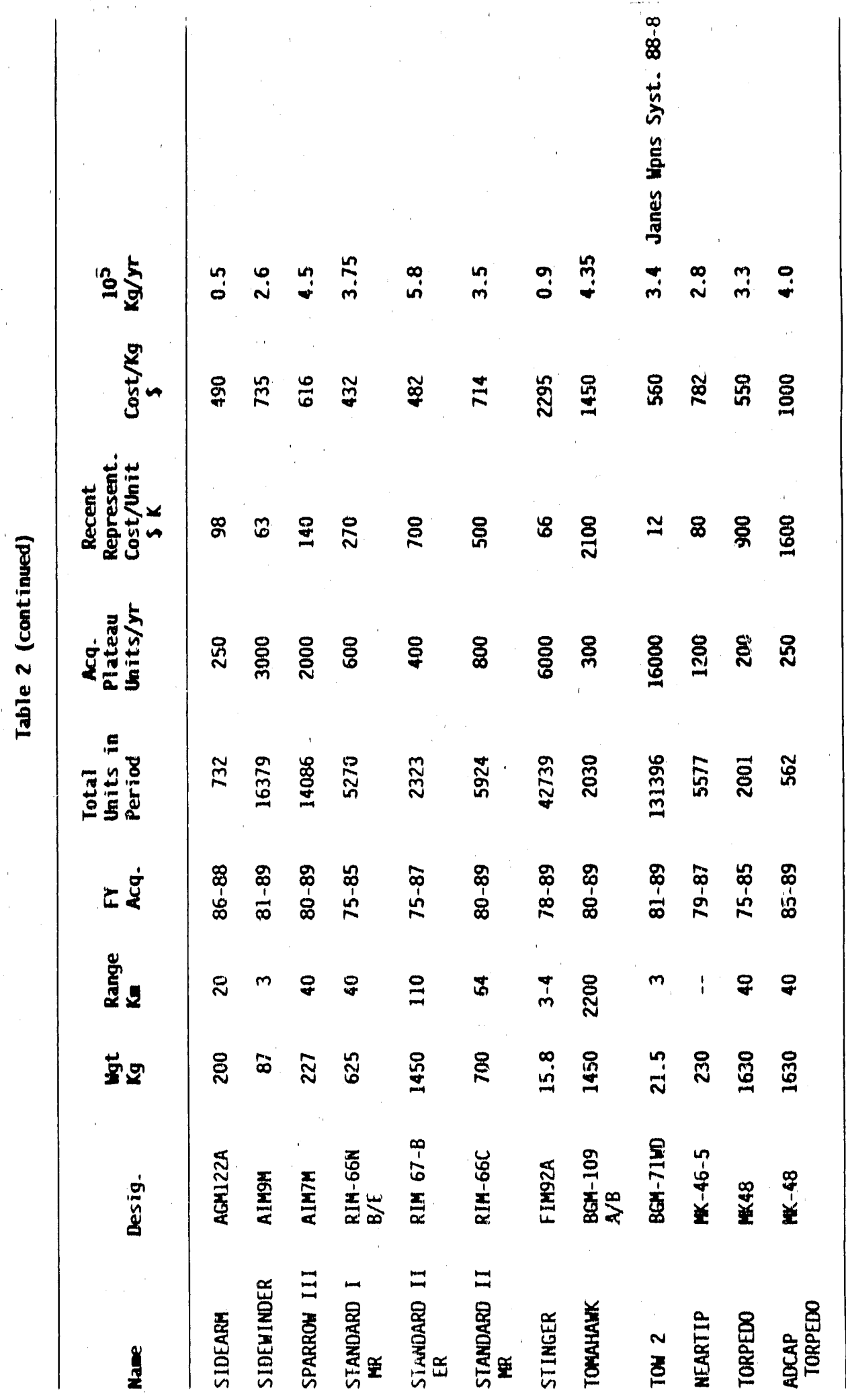


Arsenal of Democracy in the Face of Change: Precision

Guided Munitions (PGMs) Their Evolution and Some Economic

Considerations, Working Paper No. 4.

From the table and other information we can see that some of these missiles have very long production lives and long service lives, and that some have been through many modifications, such as Sidewinder and TOW. It is instructive to compare the costs with the unit costs of some of the platforms which are used to launch the missiles and are targets for similar missiles from the Soviet block (see Table 3). Typically, the missiles cost of the order of one percent of the cost of platforms.

\section{ESCALATION OF AIRCRAFT COSTS SINCE WORLD WAR II}

Table 4 is a comparison of the costs of aircraft from World War II with their prices corrected to 1985 dollars with modern aircraft currently fulfilling the same roles. The B17 Flying Fortress, a penetrating heavy bomber, in 1985 prices would cost a little over a million dollars. Our new penetrating heavy bomber B1B, cost about 97 million dollars per copy -- a little less than 90 times as much. The B1B is a far more capable aircraft llying at much higher speed for longer ranges and carrying a very much heavier bomb load, and in a much more hostile environment. The follow-on B29 Stratofortress would have cost around 3.4 million dollars in 1985, compared to 277 million dollars a copy as an early estimate for the cost of the B2 follow-on to the B1. The F4U Corsair would have cost about .5 million dollars in $198 ;$, compared with 27 million for the F18 Hornet, 36 million dollars for the F14 A-C and 62 million for the F14D -.. factors of increase running from 50-120. The F47 Thunderbolt from World 


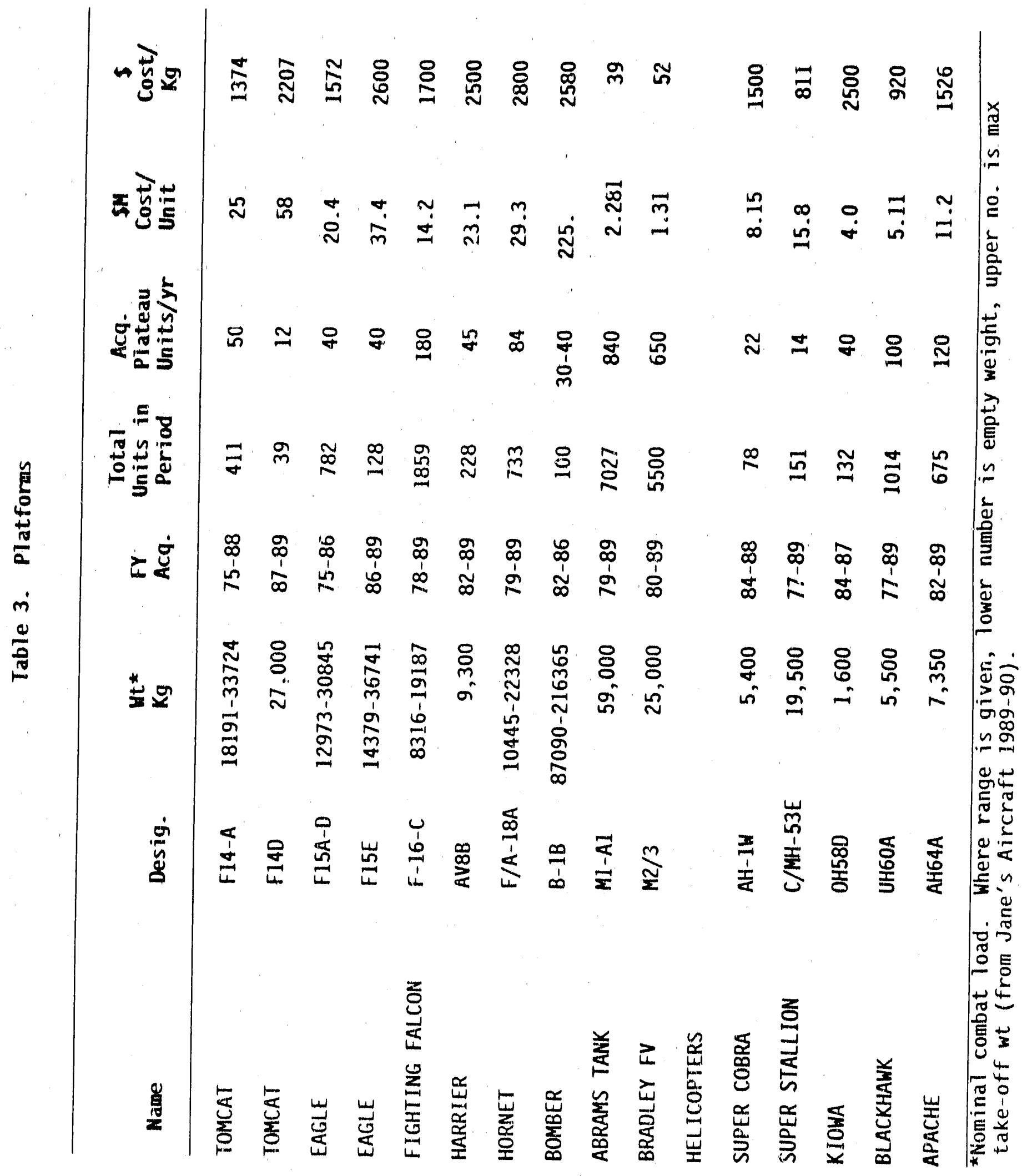


Table 4. Escalation of Aircraft Costs Since Horld Mar II

\begin{tabular}{|c|c|c|c|c|c|c|}
\hline $\begin{array}{l}\text { WWII } \\
\text { Aincraft }\end{array}$ & $\begin{array}{l}\text { Then-year } \\
\text { cost } \$ \text { MY }\end{array}$ & 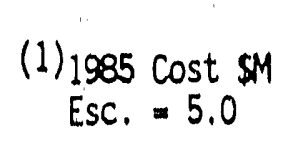 & Mission & $\begin{array}{l}\text { Equivalent } \\
1985-90 \\
\text { Aircraft }\end{array}$ & $\begin{array}{l}\text { Cost of } \\
\text { Equitv. }, \$(2)\end{array}$ & $\begin{array}{l}\text { Rat to, } \\
\text { Now/WWII }\end{array}$ \\
\hline $8-17$ & .218 & 1.09 & $\begin{array}{l}\text { Pentrating Heavy } \\
\text { Bomber }\end{array}$ & $B-1 B$ & 97 & 88 \\
\hline B-29 & .680 & 3.4 & $\begin{array}{l}\text { Follow-on Heavy } \\
\text { Bomber }\end{array}$ & B-2 & $277^{(3)}$ & 82 \\
\hline$F=4 U$ & .102 & $\therefore:$ & $\begin{array}{l}\text { Carrier Fighter } \\
\text { Attack }\end{array}$ & $\begin{array}{r}F-18 \\
F-14 \text { A-C } \\
F-14 D\end{array}$ & $\begin{array}{l}27.2 \\
36.6 \\
62.5\end{array}$ & $\begin{array}{r}53 \\
72 \\
123\end{array}$ \\
\hline$F-47$ & .089 & .445 & Heavy Fighter & $F-15 A-E$ & $35(\mathrm{Av})$ & 79 \\
\hline$F-51$ & .054 & .27 & Light Fighter & $F-16 A-D$ & 14.5 & 54 \\
\hline
\end{tabular}

(1)Dollar escalation based on R.S. Means, "Building Construction Costs Data 1985."

(2) Costs from T. Nicholas and R. Rossi, "Military Cost Handbook", (gth Ed) Data Search Assoc., Fountain Valley, CA 1988.

(3) Av. Week - I February 1988, Later estimates over $\$ 600 \mathrm{M}$. 
Arsenal of Democracy in the Face of Change: Precision

Guided Munitions (PGMs) Their Evolution and Some Economic

Considerations, Working Paper No. 4.

War II Would have cost about .45 million dollars in 1985 compared to 35 million dollars for the F15. The F51 Mustang in 1985 would have cost about .27 million dollars compared with 14.5 million for the lightweight F16, an increase of a factor of 54 . These large factors are one reason why we build so many fewer aircraft today than we did in 1943 and 44 . If technology continues to escalate the cost of aircraft, we will continue to approach the Augustinian limit of absurdity where the entire Air force budget is required to purchase a single aircraft. It is clear th.st at some point economics is going to limit this cost escalation, and force some compromises on aircraft capability.

Table 5 lists some conventional munitions. Uncomplicated bombs and shells cost a few hundred dollars per round. More complicated cluster bombs and mine distributing bombs and shells cost from a few thousand to a few ten thousand dollars per round. As has been noted earlier, scores or hundreds of "dumb" munitions can be required to take out a hardened point target that can be destroyed with a single precision-guided munitions. Often the cost of the "dumb" munitions (coupled sometimes with a loss of the platforms to deliver them) will equal and often exceed the cost of the precision-guided munitions to take out a given target. In effect we are compressing the combat effectiveness of scores or hundreds of conventional munitions into a single light package of a precision-guided munitions. This logistic compression of effectiveness can be highly advantageous if there is an expensive logistic step somewhere in the path from production factory to enemy target for the munitions. Examples of expensive logistic steps are delivery in 
Table 5. Cost of Some Conventional Munitiongt*

\begin{tabular}{|c|c|c|c|}
\hline Name & Designation & WGT Kg & $\begin{array}{l}\text { Cost } \\
\text { Unit } \\
\$\end{array}$ \\
\hline 500 16 BOMB & & 230 & $250-400^{*}$ \\
\hline 1000 16 BOMB & M83 & 454 & $300-500 *$ \\
\hline 105 HOW & & 19.5 & $\begin{array}{l}200-300 *+\$ 25 \text { for } \\
\text { powder }\end{array}$ \\
\hline 155 HOW single fuze & & 45 & $450 *$ \\
\hline 155 HOW dual fuse & & 45 & $500-550 *$ \\
\hline BIG EYE & $B L U-80 / B$ & & 52000 \\
\hline Combined Effects, Mun. & CBU -87 & 450 & 18000 \\
\hline $20 \mathrm{~mm}$ cartridge & & & $2.75-4.00^{\star}$ \\
\hline 155 MM RAP & M249 & 45 & 1000 \\
\hline $\begin{array}{l}\text { Area Denial Arty. Mun. } \\
\text { (ADAM) long life }\end{array}$ & M692 & 45 & 5000 \\
\hline $\begin{array}{l}\text { Remote Anti-armor } \\
\text { Mine Syst. RAAMS } 155\end{array}$ & M741 & -45 & 2000 \\
\hline
\end{tabular}

* Source: Personal communication to I. Gutmanis by M. J. Squires, U.S. Army Materiel Command, 5 Jan 1989.

** All other data from Nicholas; \& Rossi 1988. 
Arsenal of Democracy in the Face of Change: Precision

Guided Munitions (PGMs) Their Evolution and Some Economic

Considerations, Working Paper No. 4.

close air support by a very expensive high-performance aircraft and transport by packmule from Peshawar to Kabul.

For example, attacking a defended target that exacts an attrition rate of $2 \%$ of 50 -milliondollar F-15's statistically costs $\$ 1$ million/sortie in transportation costs. Taking out the target with 3 aircraft using 200,000-dollar PGM's is much cheaper than having to use 30 aircraft each carrying $101000 \mathrm{lb}$ bombs at $\$ 500$. The munitions costs are higher for PGM's but the delivery costs are much lower. They are lower still when the decrease in attrition rate due to the greater stand-off possible with the PGM is taken into account.

\section{FUTURE DIRECTIONS OF TECHNOLOGY}

For the future we should expect more of the same. Small technological improvements should push effectiveness of PGM's closer to the ideal of one round per target. Improvements in antiaircraft missiles that would move in this direction would be increasing the acquisition angle of the sensors, decreasing the response time of the guidance system and increasing the turning acceleration of the airframe.

We can expect a vigorous effort to reduce the exposure of the PGM operator. Routes to this end are the development of more fire-and-forget guidance systems, delivery from remotely piloted vehicles and development of a TV sensor and fiber optic link such as in the fiber optic guided missile (FOG-M) which is in effect an RPV. This last permits launch of the missile from defilade and acquisition of the target after the missile is in flight. 
We can expect more acute sensors and greater acquisition ranges and improved countermeasure resistance. For optical and IR sensors this would mean better resolution of the optical system and multispectral capability of the sensing element(s). For radar guided missiles, the prospects for improvements in resistance to jamming and spoofing are almost endless. A wide variety of improvements in sensitivity and computer-controlled frequency changes and signal processing can go on indefinitely:

The exponential increase in computer capability can be expected to continue for many years in the future. This technological improvement, which is really a decrease in price per unit computation, would be expected to manifest itself in improved capability of military hardware as well as reduced cost. This capability would be the speed of guidance computation using more complex algorithms and signal processing and hence improvements in accuracy and countermeasure resistance. One of the most urgently needed improvements is a dependable IFF (Identification Friend or Foe) capability, especially for shoulder-launched anti-aircraft missiles.

Improvements in PGM's will certainly provoke improvements in counter- measures: more realistic decoys, drones, low observable cruise missiles, as well as better radar and other defensive sensors. The net effect will probably be further improvements in the capacity of man-portable systems at the expense of vulnerability of platforms. 


\section{CONCLUSIONS}

PGM's already dominate the munitions budget and can be expected to do so in the foreseeable future (Sullivan, et al. 1988). They will remain expensive and cost-effective. They will provoke changes in tactics, technology, and countermeasures by the adversary as shown by experience in 1973 and 1982 . However, a technology race is precisely the type of race sought by the West.

The logistic compression of PGM's has resulted in greatly increasing the effective lethal range of the individual infantryman, largely to the detriment of expensive weapon platforms such as armor and aircraft.

The implications for surge and mobilization are that priority for surge and mobilization capability should be given to PGM's, especially those fired by infantry.

The constant evolution of PGM's, their targets and countermeasures is an argument for deferring large-scale production until an increase in international tension.

Surge quantities of PGM's are well within U.S. airlift capabilities, taking some of the risk out of off-shore procurement. 
Arsenal of Democracy in the Face of Change: Precision

Guided Munitions (PGMs) Their Evolution and Some Economic

Considerations, Working Paper No. 4.

\section{BIBLIOGRAPHY}

Atkeson, E.B., "The Final Argument of Kings, Reflections on the Art of War", Hero Books, Fairfax, VA 1988.

Brewer, G.D. and M. Shubik, "The War Game A Critique of Military Problem Solving", Cambridge, Mass, 1979.

Dupuy, T.N., T.P. Hayes, C.C. Johnson, P. Martel, T. Betsock, R. McQuie, "The Value of Field Fortifications in Modern Warfare", DNA 5054F-1, Historical Evaluation and Research Organization, VA 1979.

Dupuy, T.N., "The Evaluation of Weapons and Warfare:, HERO Books, Fairfax, VA, 1984.

Garden, T. "The Technology Trap", p. 111, Brasseys London 1989.

Gliksman, A. "NATO New Arms Technology. An Interview with the Office of $\mathrm{Te} \mathrm{c}$ h $\mathrm{n}$ o $\mathrm{l}$ o g y Assessment." National Defense v. 73, no. 445, p.28, February 1989.

Holmes, R., "World Atlas of Warfare", Military Innovations that Changed the Course of History", Viking Studio Books, NY 1988.

Jablonski, E., "Airwar, Vol IV. Wings of Fire," Doubleday \& Co., Garden City, NY 1972.

Nicholas, T., and R. Rossi, "Military Cost Handbook", 9th ed., 1988.

..........-., "U.S. Weapon System Costs", Eight ed., Data Search Associates, Fountain Valley, CA 1988.

Sliwinski, M., "The Decimation of a People", ORBIS, Vol. 33, No. 1, pp. 39-56, 1989.

Sullivan, L., D.E. Carson, L.G. Pannier, "DOD NATO Munitions Acquisitions Strategy", TR5543 (Draft), The Analytic Sciences Co., Arlington, VA, March 1988.

U.S. Army, "Infantry, Airborne and Air Assault Brigade Operations", FM7-30, 1982.

U.S. Army, The Infantry Platoon and Squad, FM7.-8, Rev. 1984. 
Arsenal of Democracy in the Face of Change: Precision

Guided Munitions (PGMs) Their Evolution and Some Economic

Considerations, Working Paper No. 4.

\author{
ORNL Project Working Papers for \\ Arsenal of Democracy in the Face of Change
}

Bjornstad, David J. and Paul Sullivan with Conrad V. Chester, Rajeev K. Goel, David A. Trumble, and Ivars Gutmanis, "Arsenal of Democracy in the Face of Change: Industrial Mobilization Issue Identification and Literature Review, Working Paper No. 1," ORNL/TM-11272, October 1989.

Bjornstad, David J. and Barbara H. Hardy, "Arsenal of Democracy in the Face of Change: Issues and Policy Options in Industrial Preparedness Planning, Working Paper No, 2," ORNL/TM-11273, October 1939.

Brinkerhoff, John R., "Arsenal of Democracy in the Face of Change: Issues Underlying the Implementation of Industrial Mobilization Policy, Working Paper No. 3," ORNL/TM-11274, October 1989.

Chester, C. V., "Arsenal of Democracy in the Face of Change: Precision Guided Munitions (PGMs) Their Evolution and Some Economic Considerations, Working Paper No. 4," ORNL/TM-11275, July 1990.

Horwich, George, "Arsenal of Democracy in the Face of Change: Four U.S. Mobilizations: A Macroeconomic Perspective, Working Paper No. 5," ORNL/TM-11276, October 1989.

Sullivan, Paul, "Arsenal of Democracy in the. Face of Change: Issues in the International Economics of Industrial Mobilization and Surge for Crisis in an Interdependent World, Working Paper No. 6," ORNL/CF-90/52, March 1990.

Trumble, David A., "Arsenal of Democracy in the Face of Change: Computer Programs for Micro Analysis of Surge and Mobilization Capability: Review and Recommendations, Working Paper No. 7," ORNL/TM-11279, November 1989. 
Arsenal of Democracy in the Face of Change: Precision

Guided Munitions (PGMs) Their Evolution and Some Economic Considerations, Working Paper No. 4.

\section{LIST OF ACRONYMS}

PGMs - Precision Guided Munitions

PLSS - Precision Location Strike System

I-STARS - Joint Surveillance and Target Attack Radar System

RPVS - Remotely piloted vehicles

SADARM - Seek and destroy armor

FOFA - Follow-on force attack 

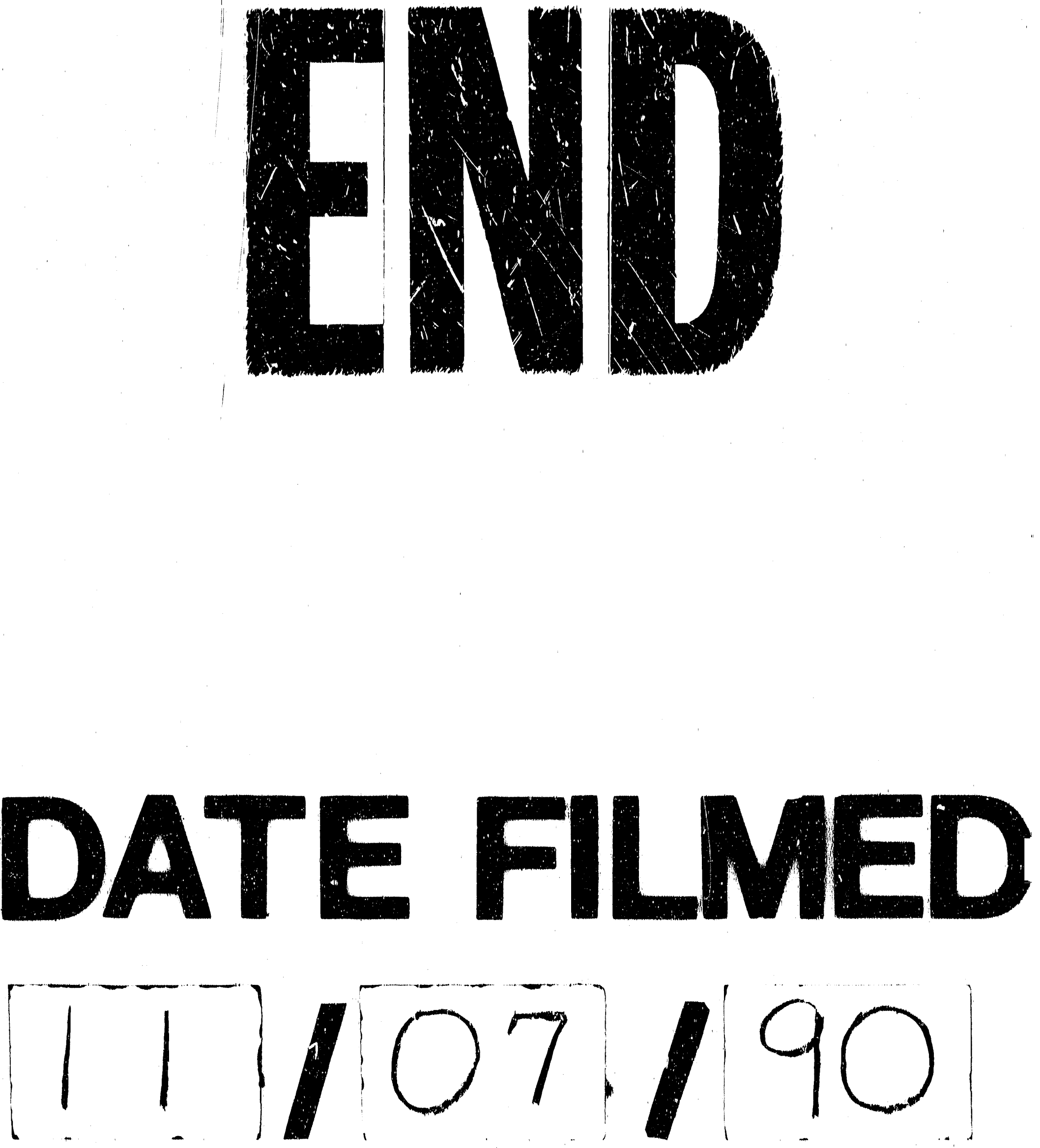
